MIROSŁAWA PODHAJECKA

University of Opole

mira.podhajecka@wp.pl

\title{
LUDWIK KRZYŻANOWSKI'S ENGLISH-POLISH LEXICOGRAPHIC PROJECTS: EVIDENCE FROM THE PIASA ARCHIVES ${ }^{1}$
}

Keywords: PIASA, bilingual dictionary, lexicography, analysis

\begin{abstract}
The present paper is a contribution to the history of Polish-English and English-Polish lexicography. It aims to throw some light on two bilingual dictionaries compiled by Ludwik Krzyżanowski, which have so far been shrouded in mystery. Fonds no. 49 deposited in the New York archives of the Polish Institute of Arts and Sciences of America (PIASA) provide archives in New York provide valuable data on the author and his scholarly activity, as well as a tiny part of a dictionary typescript that allows for a preliminary assessment of the lexicographic endeavour.
\end{abstract}

\section{Introduction}

This paper is a contribution to the history of Polish-English and English-Polish lexicography which has received little attention so far; a chapter in Piotrowski's monograph Zrozumieć leksykografię (2001), describing the main dictionaries with Polish and English as the source or target languages, remains the only comprehensive study in the field. As a result, we know very little about printed dictionaries and even less so about those extant in the manuscript form. ${ }^{2}$

1 This paper is part of a project in the history of Polish-English / English-Polish lexicography (1788-1947) supported by the Polish National Science Centre (DEC-2011/01/B/HS2/05678).

2 In chronological order, these are: Do Stownika Angielsko-Polskiego Dodatek ktorego układanie przedsięwzięte zostało Roku 1799 Dnia 17 stycznia, an anonymous manuscript dictionary in the holdings of the National Library of Ukraine in Kiev (Siekierska 1985); Michał Wiszniewski's 
The aim of this paper is to throw some light on two lexicographic projects undertaken by Ludwik Krzyżanowski, a scholar educated at the Jagiellonian University, a prolific translator and an active promoter of Polish literature and culture in the West. Since a tiny part of a dictionary typescript has been discovered in the archives of the Polish Institute of Arts and Sciences of America (PIASA) in New York, ${ }^{3}$ it is examined in some detail as a sample of the whole endeavour. Additionally, the PIASA archival materials are explored to help establish facts from the past.

\section{Prologue}

The paper owes more to serendipity than to systematic research. More exactly, investigating the history of Polish-English and English-Polish lexicography, I came across Ludwik Krzyżanowski's article published in The Polish Review (1957), which offered a description of an ideal bilingual dictionary which, in the author's view, still needed to be compiled:

This need was strongly felt even in pre-1939 Poland. The well-known Warsaw publishing house Trzaska, Evert and Michalski undertook the publication of modern dictionaries of the Western European languages. At the suggestion of the late Professor Roman Dyboski of Cracow University, Poland's foremost authority in the field of English language and literature, the present writer was in 1937 entrusted with the preparation of an English-Polish and Polish-English dictionary which according to the stipulations of the contract was to be at least twice the size of the then existing dictionary previously published by the firm. Until the outbreak of World War II, the English-Polish part had been brought up to the letter "O". Unfortunately all the materials and the plates already set in type were lost when the installations of the printing establishment in Cracow were destroyed, as a result of the Nazi invasion (Krzyżanowski 1957: 100).

The discovery, which came as a complete surprise, became an impetus to collect information on the lexicographer and his works, which, in turn, led me to the Ludwik Krzyżanowski fonds in the PIASA archives. My letter of inquiry was responded to by a Polish archivist who browsed on my behalf through a huge volume of documents in the search for anything that would be related, in one way or another, to the dictionary in question. ${ }^{4}$ The search resulted not only in finding interesting archival sources, but also a minuscule portion of an English-Polish dictionary.

Słownik polsko-angielski z porównaniem Języka Angielskiego z Polskim at the Ossolińskis Library in Wrocław (A-F), Jagiellonian Library in Cracow $(\mathrm{G}-\mathrm{H})$ and the Ossolińskis Library in Lwów (drafts of G-Z); Paweł Sobolewski's Słownik Angielsko-Polski, zawierajacy wsobie wszystkie słowa i frazesa w powszechnem użyaniu ... in the holdings of the Polish Library in Paris (B-E); Wincenty Trybulski's Stownik angielsko-polski (not found) and Ludwik Krzyżanowski's English-Polish dictionary (A-O) destroyed by the Nazis in 1939 (Krzyżanowski 1957: 100). The first part of Wiszniewski's dictionary is the subject of Jajdelski's analysis (2002), while Sobolewski's dictionary has been investigated by Podhajecka [forthcoming].

3 The history of PIASA is offered by Nowożycki (2011). 
At the same time, I came across a detailed biography of Ludwik Krzyżanowski written by Dorosz on the basis of archival sources available from the PIASA and the Polish Library in London. She argues that, in 1949, Krzyżanowski "undertook the compilation of an exhaustive English-Polish and Polish-English dictionary, interest in whose publication was declared by Marian Kister of "Roy Publishing" in New York. ${ }^{5}$ Representatives of the Polish Institute of Arts and Sciences sought the financial support of the National Committee for Free Europe for that venture; due to financial and organisational difficulties, however, the substantially advanced project was not seen to fruition" [M.P.] (Dorosz 2010: 271-272). It brought my research to a standstill; the riddle that had to be solved was: was there only one dictionary or two? Should the latter scenario be true, what happened to the allegedly advanced manuscript prepared for "Roy Publishing" and why is there no single mention of it in Krzyżanowski's paper? This and other research questions will be addressed through an analysis of the dictionary and the PIASA materials.

\section{The lexicographer ${ }^{6}$}

Ludwik Krzyżanowski was born in Krosno, on 10 November 1906, to Józef Krzyżanowski and Jadwiga (née Lubomęska) His father was later employed in Vienna, but, when Poland regained her independence in 1918, the family returned to Cracow. After completing the Jan III Sobieski Gymnasium, Ludwik enrolled at the Jagiellonian University to study English language and literature. He was no doubt an exceptional student, for he continued his studies in Cambridge and, as an exchange grantee of the Kosciuszko Foundation, in Chicago. After graduation, he became an assistant to Professor Roman Dyboski, ${ }^{7}$ under whose mentorship he wrote and, in 1932, defended his doctoral dissertation entitled "Joseph Conrad: A Polish Introduction" (AUJ). In 1932-1938, he taught English at local schools and, ${ }^{8}$ as archival materials show, worked actively as a translator. ${ }^{9}$

4 I owe a debt of gratitude to Dominik Wołącewicz, whose assistance was essential in my research. My thanks go also to Patrycja Roman for providing me quickly with scans of selected documents.

5 Marian Kister was a co-owner and financial director of "Rój", a publishing house founded by Melchior Wańkowicz in Warsaw. After 1939, the Kisters wandered across Europe with the intention of emigrating to the United States and wrote to many influential Poles, including Ludwik Krzyżanowski, for help in getting to America (PIASA). After settling in New York, they ran a publishing house ("Roy Publishing") which specialised in Polish literature in English translation. Throughout the war, they also reprinted Stanisławski's 1929 dictionary and, after the war, his 1948 abridgement (as Newest pocket English-Polish and Polish-English dictionary [Stanisławski 1948]), but the latter was not a commercial success.

6 The biographical details come from Krzyżanowski's biography by Dorosz (2010), memories by Gross et al. (1981), the biographies found in the PIASA archives, an obituary in the New York Times (Obituaries 1986), as well as the AUJ sources.

7 Krzyżanowski's "Roman Dyboski: Tribute of a pupil” (PIASA) offers a personal view of Dyboski's achievements. For other accounts, see Bela and Mańczak-Wohlfeld (1998). 


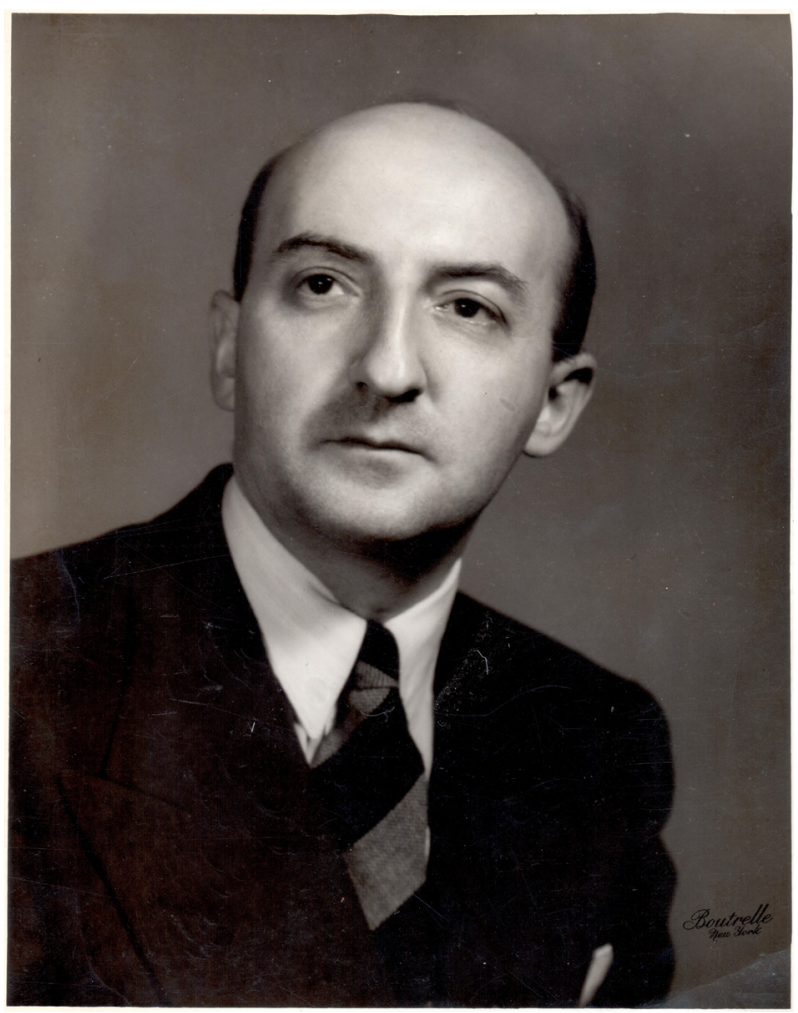

Fig. 1. A photograph of Ludwik Krzyżanowski (courtesy of PIASA). ${ }^{10}$

In 1938, upon the recommendation of his former supervisor, he went to the United States as an educational and cultural officer of the Polish Consulate in Chicago (later New York). After the outbreak of the war, he was transferred to the Information Service of the Polish government-in-exile and subsequently served as a regional specialist for the US Government Office of War Information. Between 1940 and 1942, he was editor-in-chief of New Europe, a monthly devoted to international affairs and, in 1944, worked briefly at the United Nations Relief and Rehabilitation Administration (UNRRA). In 1946, he became a permanent resident of the United States. ${ }^{11}$

8 For example, B.W.A. Massey from Poznań University commissioned him to translate a handbook in Basic English, although it is unclear whether or not the task was fulfilled (ARCM). Krzyżanowski's later literary translations are richly documented in the PIASA archives.

9 He was a teacher of English at the Hotel School in Cracow (see Szkoła Hotelarska... 1935: 23, 37) and the State Coeducational School of Commerce at Biała Krakowska (see Sprawozdanie dyrekcji... 1938: 6).

10 The photograph was taken at the New York atelier of Adrien Boutrelle, probably in the mid1940 os in New York (the note on the reverse is partly illegible).

11 This notwithstanding, there were periods in Krzyżanowski's life when he was experiencing dramatic hardships. One of them is mentioned in a letter to Wierzyński of 3 April 1948 (Dorosz 2010: 283). 
In 1946-1947, he found employment as a precise writer and English-French translator at the Editorial Division of the United Nations in New York but was forced to resign under the pressure of the Polish delegation to the UN. He also worked as an economic and political consultant for Eastern Europe at the International Nickel Company in New York. In 1948, after a short stay at the Army Language School at Monterey, California, Krzyżanowski became a lecturer and professor in Polish language and literature at the Polish School of General Studies of Columbia University in New York and later served as professor and faculty advisor at the Section of Languages and Culture of the Department of Political Science of New York University. ${ }^{12}$

He published extensively on aspects of literature, culture and politics. Among others, he translated into English For your freedom and ours: Polish progressive spirit through the centuries (Kridl et al. 1943) and The democratic heritage of Poland (Kridl et al. 1944) and was the editor of Poland in world civilization (Dyboski, Krzyżanowski 1950), Joseph Conrad: Centennial essays (Krzyżanowski 1960) and Julian Ursyn Niemcewicz and America (Krzyżanowski 1961). In collaboration with Adam Gillon, he edited Introduction to modern Polish literature ... (Gillon, Krzyżanowski 1964) ${ }^{13}$ and Joseph Conrad: Commemorative essays ... (Gillon, Krzyżanowski 1975). In 1942, he was one of the founders of the Polish Institute in Manhattan (later renamed the Polish Institute of Arts and Sciences of America) and, in 1956, agreed to be editor-in-chief of the Polish Review (1956-1986), the Institute's scholarly journal. He died of a heart attack at Shannock, Rhode Island, on 16 March 1986.

\section{The bilingual dictionary markets}

Due to Poland's complicated political situation, up to the mid-twentieth century, English-Polish and Polish-English dictionaries were few and far between. To make things worse, the most comprehensive dictionary, Erazm Rykaczewski's A complete dictionary English and Polish and Polish and English ... (1849-1851), whose subsequent editions and reprints appeared under the name of Aleksander Chodźko, was painfully outdated. A huge demand for bilingual dictionaries encouraged the publishing house of Trzaska, Evert and Michalski (TEiM), one of the strongest publishers in the Second Polish Republic (1918-1939), to launch onto the market a new Polish-English and English-Polish dictionary edited by Władysław Kierst, who had already made his name as the author of two smaller bilingual volumes. ${ }^{14}$ The dictionary, whose

12 Krzyżanowski was employed at the Polish School of Columbia University after A.P. Coleman, a lecturer in Polish at the Slavic Department, resigned in a protest against obtaining financial support for the school from the communist Polish government (see, e.g., Pastusiak 2002 : 134-137).

13 The volume included his own translations of excerpts from Polish authors (see Dorosz 2010: 273).

14 Słownik języka polskiego i angielskiego. English-Polish and Polish-English dictionary (1895), allegedly compiled in co-operation with Oskar Callier, was published by the Leipzig-based "Otto Holtze" publishing house of Otto Holtze. The ensuing dictionary, Dokładny słownik 
Polish-English part came out in 1926 and the English-Polish one in $1928,{ }^{15}$ was soon acclaimed a huge commercial success (Pieczonka 1993: 42) ${ }^{16}$ In 1929, Jan Stanisławski, a lecturer in English at the Jagiellonian University, published a new dictionary (Stanisławski 1929) whose lexical coverage was comparable to Kierst's. ${ }^{17}$ That volume, as well as its subsequent abridgement, A new English-Polish and Polish-English dictionary (Stanisławski 1945), strengthened Stanisławski's reputation as the leading English-Polish lexicographer. Additionally, users had at their disposal a handful of small dictionaries, including pocket (e.g. Słownik miniaturowy "Dux" angielsko-polski i polsko-angielski (1920) by Stanisław Goldman) and miniature editions (e.g. A miniature Polish-English and English-Polish dictionary (1910) by Michał Dziewicki).

One cannot forget about the overseas markets, especially the Polish diasporas in Great Britain and the United States. Since the mid-nineteenth century onwards, thousands of people left Poland for political causes, whereas others sought a new home mainly for economic reasons. Some of the newcomers who were fluent in English employed their language skills to cater to the less fortunate fellow countrymen. In this way, Antoni Paryski (Słownik polsko-angielski i angielsko-polski oraz nauka wymowy angielskiej, 1899), Modest Maryański (Jedyny w swoim rodzaju przewodnik polsko-angielski i słownik polsko-angielski ..., 1906), Leonard Szumkowski (Dykcjonarz kieszonkowy polsko-angielski i angielsko-polski ..., 1908), Tadeusz M. Wilde (Słownik Smulskiego angielsko-polski i polsko-angielski ..., 1928) and J.K. Socz (Słownik polsko-angielski i angielsko-polski z wymowa ..., 1944) became lexicographers out of necessity, so to say. Still, their dictionaries were small, unsophisticated and targeted at inexperienced users.

Importantly, none of the authors - perhaps with the sole exception of Erazm Rykaczewski - was a genuine linguist, which explains, at least to some extent, why the bilingual dictionaries were imperfect. Ludwik Krzyżanowski, with his profound knowledge of Polish and English and the status of a literary scholar, was far better prepared for the lexicographic profession than any of his predecessors. In this context, it is no wonder that he decided to contribute to the Polish-English / English-Polish dictionary-making tradition. Ideally, he would do so for the love of lexicography, but it is obvious that the project was expected to be an additional source of income.

angielsko-polski i polsko-angielski $w$ dwóch częściach z wymowa wyrazów angielskich (1915-1916) appeared in fascicles under the imprint of "Księgarnia Mazowiecka", but it was left unfinished.

15 Pieczonka (1993: 41-42) states wrongly that the first volume appeared in 1925 and the other one in 1930.

16 The new dictionary was not a quantum leap, because it drew on the 1895 edition published by Kierst and Callier, but the author went to great lengths to bring it up to date. For this purpose, he added new vocabulary reflecting changing realia, a better choice of illustrative examples and pronunciations in a simplified phonetic alphabet. The last feature, in particular, was expected to make the dictionary a successful learning tool without a foreign language course or teacher.

17 The bilingual dictionary was commissioned by J. Lorenz, a Moravian publisher, and published at Třebič in 1933. In 1929, however, the same dictionary material had been published in Warsaw, under a slightly different title, by "Księgarnia Wysyłkowa Dorna”. A typed copy of the contract is available from the Tomasz Niewodniczański's Collection (TNC) deposited at the Warsaw Royal Castle. 
Let us now concentrate on Krzyżanowski's description of an ideal bilingual dictionary pairing Polish and English.

\section{The PIASA archives}

\subsection{An ideal English-Polish dictionary: Krzyżanowski's 1957 article}

Describing the plight of Polish-English and English-Polish lexicography, Krzyżanowski explained why a brand new dictionary was needed. One of the reasons was the situation in post-war Poland and, in consequence, a flood of Polish refugees in the West. The lexical content was a challenge; as the author put it, "[T]he contact with new conditions, surroundings, situations produced its quota of words and phrases. The entirely changed political situation and the thorough social transformation, new concepts and institutions of post war Poland are constantly leaving their imprint on the language" (Krzyżanowski1957: 100). This indicated that, after World War II, speakers of Polish and English lacked a dictionary which would incorporate all the lexical and semantic novelties of the respective languages.

To compile a dictionary like that, Krzyżanowski recommended the use of a card system, in which words and senses would be produced on slips of paper for the Polish and English wordlists. As for the sources of data, he suggested that the lexicographers should use the existing dictionaries, as well as "a number of newspapers, periodicals of various types, novels, technical books etc. and search for words, phrases, idioms, technical terms, abbreviations that have come into use in recent years" (Krzyżanowski 1957: 101). In his opinion, meanings should not be presented on the historical basis but should be grouped from the most to the least current and phraseological items should be listed separately. To help the user navigate through the dictionary, a crossreferencing structure should be built. Technical terms were to be preceded by field markers, Polish headwords being accompanied by adequate grammatical information. As for pronunciations, American English should be given prominence, but British English variants should also be recorded, both of which should appear in the International Phonetic Alphabet (IPA). A range of experts ought to be employed in order to make sure that the treatment of the vocabulary was up-to-date.

Ensuring cross-linguistic equivalence was the greatest problem. As Krzyżanowski (1957: 102) put it, "a dictionary must be a record of the diction, of the phrasing and idiom peculiar to the language under consideration (...) Due to the differences in language, due to the lack of some concepts in one of the languages in question, this practice cannot be wholly avoided, but it definitely should be a last resort and not the rule." Speaking of the prospective size, the author would expect a "comprehensive, reasonably encyclopedic, dictionary of the living language, comprising about 60-75,000 words", which would be a reliable tool for a range of target users and "a modest, but nevertheless necessary link in the cultural rapprochement" (Krzyżanowski 1957: 102) between Poland and the United States.

Assuming that the author endeavoured to compile such a dictionary, he never saw it to completion. Yet his dream did materialise in the United States: the bulk of 
the dictionary material was compiled by Kazimierz Bulas, a Polish archaeologist, ${ }^{18}$ and published under the auspices of the Kosciuszko Foundation. Entitled Kosciuszko Foundation English-Polish and Polish-English dictionary (1959-1961), it was eventually the work of Kazimierz Bulas and Francis J. Whitfield (Bulas, Whitfield 1959), as well as Lawrence Thomas in the Polish-English part (Bulas, Thomas, Whitfield 1961). By contrast, the Polish market was filled out by the dictionary compiled by Jan Stanisławski and edited by Wiktor Jassem under the imprint of "Wiedza Powszechna", a state publishing house; the English-Polish part appeared in 1964 (Stanisławski 1964), whereas the Polish-English one in 1969 (Stanisławski 1969). The two dictionaries virtually monopolized the two markets, foreign and domestic, until the turn of the twenty first century.

\subsection{An ideal English-Polish dictionary: Krzyżanowski's drafts}

The Krzyżanowski fonds in the PIASA archives offer two mixed drafts of the abovementioned article, of which one is hand-written and the other one is a machine typescript. What makes them interesting is the fact that they contain passages which did not go into the final version.

The manuscript focuses on Lilien's dictionary, an English-Polish dictionary modelled on American encyclopedic dictionaries, whose compilation was undertaken by Ernest Lilien (1944-1951), a retired journalist of Polish origin residing in Stevens Point. It was planned to be the largest English-Polish dictionary, but its publication was stopped abruptly by the author's death in 1952. Krzyżanowski starts by summarising the project, adding that "the undertaking was tremendous and due tribute is deserved by the man who started it". However, he also levels harsh criticism on Lilien's lexicographic principles, claiming that the home-made version of phonetic notation is inadequate and inconsistent, many entries are descriptions rather than translations and the "most common terms" (like "pracodawca" and "chlebodawca" for employer) are not recorded at all. This shows, beyond all doubt, that Lilien's dictionary did not match Krzyżanowski’s ideal.

The typescript offers various ideas which did not find their way into the published article. To provide a few examples, Krzyżanowski suggests that pronunciations should also accompany Polish headwords "making the dictionary more usable for non-Polish speakers" (p. 5) and the accumulated bilingual material which will not go into the dictionary proper may be useful for "technical or special dictionaries" (p. 7). Speaking of the duration of the project, he expresses hope that, "with sustained and diligent effort, the work may be brought to a successful conclusion in approximately a year and a half" (p. 7). The last point is particularly intriguing, because, in his own experience as a lexicographer, Krzyżanowski must have realised that such a tight deadline was simply impossible to keep.

Significantly, the typescript of the paper includes a list of dictionaries which could be taken into account in the compilation of a comprehensive English-Polish

18 Bulas' biography has been written by Supruniuk and Supruniuk (2012: 24-25). 
and Polish-English dictionary. Among bilingual dictionaries, Krzyżanowski mentions Chodźko's A complete dictionary English and Polish... (Rykaczewski 1874), Kierst and Callier's Pocket-dictionary of the Polish and English languages (Kierst, Callier 1906), Trzaska, Evert \& Michalski's A dictionary English-Polish, PolishEnglish... (Kierst 1926-1928), Stanisławski's An English-Polish and Polish-English pocket-dictionary (Stanisławski 1933) and Lilien's dictionary, up to the letter " $F$ " (Lilien 1944[-1951]). ${ }^{19}$ The list of monolingual dictionaries embraces, for instance, Baker's Cassell's new English dictionary (Baker 1920), Fowler's Concise Oxford dictionary of current English (COD), ${ }^{20}$ the Century dictionary ([Whitney] 1913), ${ }^{21}$ Murray's Shorter Oxford English dictionary (SOED), ${ }^{22}$ Fowler's A dictionary of modern English usage (Fowler 1927) and Jones' An English pronouncing dictionary (Jones 1932)

\subsection{The English-Polish dictionary: Jan Goldman's letter}

It is not surprising that, with a growing interest in English as a foreign language in pre-war Poland, the TEiM publishing house came up with the idea of putting out a more exhaustive dictionary than Kierst's concise volume. This is taken as a solid fact, although we can only rely on Krzyżanowski's words, as no documentation has survived to this day; even a detailed monograph on the history of the TEiM publishing house (Pieczonka 1993) does not provide any information on the above project.

The PIASA archives include Jan Goldman's letter to Ludwik Krzyżanowski which has transpired out to be a mine of information in this respect. It is noteworthy that Jan Goldman, the son of Stanisław Goldman, ${ }^{23}$ studied French and English at the Jagiellonian University and, in 1930, defended his doctoral dissertation written under the supervision of professor Stanisław Wędkiewicz (AUJ). ${ }^{24}$ Krzyżanowski and Goldman were thus university colleagues, who might have also been tied by friendship. The letter, in my translation, is reproduced below in its entirety, ${ }^{25}$ retaining the graphic and stylistic features of the Polish original.

19 In fact, the last (nineteenth) fascicle of Lilien's dictionary ends with the entry for hellbind.

20 The Concise Oxford dictionary (COD) by the Fowler brothers, first published in 1911, is an abridgement of the first edition of the Oxford English Dictionary (1884-1928). A history of the COD has been described by Kamińska (2014).

21 The Century dictionary, compiled by the Sanskrit scholar Dwight Whitney (1889-1891) and published originally in six volumes, represented the American tradition of encyclopedic dictionaries. The 1895 edition appeared in ten volumes and the 1913 edition in twelve.

22 The SOED is a scaled-down version of the Oxford English Dictionary in two volumes.

23 Stanisław Goldman, the founder and owner of "Księgarnia Lingwistyczna" and "Szkoła Ansona", was a lexicographer and author of textbooks for the teaching of foreign languages, some of which appeared under the pseudonym of Robert Anson.

24 Jan Goldman's biography has been offered by Rospond (1946: 165-166) and Strzałkowa (1959/1960: 210-211).

25 Establishing the authorship of the letter was fraught with difficulty. Fortunately, the letter is accompanied by an envelope with the logo of the Anson School of Languages ("Szkoła Ansona"), which turned out to be a reliable proof of identity. 
29 October 1938

Dear Ludwik,

I am first of all enclosing my words of sympathy and sorrow because of the sudden death of your beloved Brother. It was no longer possible to help him here in Kraków. We are sharing your pain. ${ }^{26}$

A daughter was born to us yesterday; the mother and the baby are very well. The daughter will be named Felicja (after my Father's mother). My dear Father is feeling better than one might expect and apart from that everything is back to normal. The school's going exceptionally well: 280 students (!), plenty of work. As you may guess, during the school year I have very little time for the Dictionary. This issue is very sad in general. The director, Michalski, was in Kraków, ${ }^{27} \mathrm{I}$ had a phone call from the printing office telling me to come - I said I was busy at school - why talk to them when you're not writing if you're going to make the Dictionary or somebody else will have to be employed. They promised me on the phone that another 1000-1500 zloty will be sent soon and that was it.

As for me, I'll be glad to do something, e.g. from $\underline{\mathrm{U}}$ to $\underline{\mathrm{Z}}$, but I can only make the six long letters (O P Q R S T) before the six short ones (U V W X Y Z) in April; it is all the worse that due to your silence I'm not doing anything either, since I don't know if you're not writing the other letter sections. Adela is now at the insurance company, ${ }^{28}$ tomorrow is Sunday, Tuesday is a festival, another festival comes next week, I might do something but I don't know what - and then I'll be inundated with work again. Dear Ludwik, please send me $\mathrm{C}$ as there is a huge gap and let me know how things are.

I'd be happy if you or your Lady could forward the whole sections O-Ż. Imagine that in Poland changes are now looming on the horizon, to the right or to the left; you may come to Poland, a job is hard to find, and the dictionary would give you 10 ooo-12 ooo zloty over 3-4 years. I always hoped that you would be secured - but a stranger will come instead, Michalikówna or somebody else (...). ${ }^{29}$ Believe me that I'd like the best for you, and I myself am working on the Dictionary in the time that should be devoted to rest and family joys.

Bowing and kissing your Lady's hands,

Jasiek

26 This reference is ambiguous, because Krzyżanowski's younger brother Józef (called Dzidek) fled to the West and, after a stay in France, ended up in Great Britain, where he joined the Polish Army. Sadly, he died in London in 1943. Many (if not all) of his letters and postcards to Ludwik Krzyżanowski can be found in the PIASA archives.

27 Jan Michalski was one of the owners of the TEiM publishing house.

28 It should be understood as a hospital or clinic.

29 Krystyna Michalik, Roman Dyboski's assistant, would later become a lecturer in English and head of the Foreign Languages Department at the Jagiellonian University (AUJ). 
Despite some inconsistency in Goldman's line of argumentation, it is clear that he was also commissioned with making the dictionary, which is confirmed by his acting as a party in the negotiations with the publisher. It is therefore difficult to say why Krzyżanowski did not openly acknowledge the cooperation in his article. ${ }^{30}$ Any hypothesis offered at this juncture will obviously be highly speculative, but perhaps the cooperation did not satisfy his requirements or Goldman's contribution, if any, was less conspicuous with hindsight. Moreover, it is hard to guess from the contents of the letter how the labour was divided, that is, who worked out the compilation principles, who was responsible for which letter sections and who, at the end of the day, would do the proof-reading.

In any case, the offer from the TEiM publishing house must have indeed come from Roman Dyboski, because the potential need to turn to Krystyna Michalik for help points clearly to the shape of the social network. After all, the pool of specialists in English in pre-war Poland was significantly limited. ${ }^{31}$ What is baffling, however, is both of the compilers' casual attitude to the task they were entrusted with; since the compilation was (and was to be) generously paid for, it remains an odd element of the puzzle. It makes one wonder whether the first half of the dictionary (A-O) was indeed complete in a year's time or whether the outbreak of World War II was a mere pretext to give up the project altogether. ${ }^{32}$ It remains to be established who informed Krzyżanowski of the fate of the dictionary, insofar as Jan Goldman left Cracow in 1939 (Strzałkowa 1959/1960: 211), arguably before the Nazi invasion.

\subsection{The English-Polish dictionary}

\subsubsection{Overview}

The part of the dictionary discovered in the PIASA archives encompasses 18 pages covering with English headwords from $O$ to odontalgia. It is deposited in a large envelope marked as "Słownik", with the name of Prof. E. J. Simmons in the upper left-hand corner. ${ }^{33}$

The text is machine typed throughout, except for the missing phonetic transcription, missing symbols for specific phonemes (e.g. $/ \Lambda /$ in the pronunciation for occult) and missing equivalents. The first line is pushed to the left. The headwords are entered in a lower-hand letter and are underlined; it goes without saying that differentiated typography was not available with a typewriter. Both the main and

30 The cruelties of World War II were felt strongly by American Polonia, so Krzyżanowski must have inquired about Goldman who - as a Jew - was in a great danger. In a postcard sent from Paris, Krzyżanowski's brother, Józef, informs him that he does not know anything about Goldman (PIASA).

31 B.W.A. Massey, searching for competent Polish-English translators in Poland, mentions only three Ph.D. holders: Marian Arend in Poznań, Ludwik Krzyżanowski in Cracow and Tadeusz Grzebieniowski in Warsaw (ARCM).

32 The article was published in 1957, when Dyboski and the Goldmans were no longer alive; Dyboski died in 1945, whereas the Goldmans were killed by the Nazis in Lwów in 1942.

33 It is likely that Ernest J. Simmons, chairman of the Slavic Language Department at Columbia University, was asked to review the draft dictionary to assess its scholarly potential. 
secondary headwords are followed by pronunciations in the IPA, ${ }^{34}$ grammatical information limited to part-of-speech labels and Polish equivalents. Senses are numbered and are sometimes enhanced with examples of use. Derivatives and compounds are clustered alphabetically in the entry, which exemplifies niching rather than nesting (see Fig. 2 below).

\subsubsection{The macrostructure}

Krzyżanowski's wordlist is comparable to Rykaczewski's; the alphabet range under analysis includes 154 headwords compared to 160 in Rykaczewski (1849), 83 in Kierst (1926) and 76 in Stanisławski (1929). The alleged similarity notwithstanding, Krzyżanowski used the niching principle more frequently, so the overall number of the main and secondary headwords in his dictionary is larger by far.

This suggests that Krzyżanowski turned to monolingual dictionaries for a suitable selection of English headwords. Interestingly, although he claimed that a new dictionary needed to include lexical novelties, all the main headwords and a predominant majority of the secondary headwords were by no means new in the midtwentieth century. On the contrary, many turn out to have been obsolete and rare lexical items (e.g. oakum, obit, obley, obloquious, obreption, obsecrate, obsidious, obtenebrate, obus, ochraceous, octastich and odic), whose inclusion in a dictionary of contemporary English is, at best, debatable. But, then, a small sample cannot be seen as fully representative of the whole dictionary.

\subsubsection{The microstructure}

\subsubsection{Information on pronunciation}

As already stated, Krzyżanowski provides phonetic transcription in the IPA, which must have been more useful to EFL learners than other methods of transcription, but many headwords are followed by blanks. This suggests that they were borrowed from dictionaries with a different system of notation (e.g. COD or SOED). The lexicographer probably copied the IPA pronunciations from An English pronouncing dictionary (1932) by Daniel Jones, a distinguished British phonetician. However, despite including as many as 50,00o headwords, Jones' dictionary did not record every English word admitted into bulky dictionaries, which may account for the inevitable blanks in Krzyżanowski's sample.

\subsubsection{Grammatical information}

As the sample of the dictionary comes from the middle of the alphabet, no front matter explaining the abbreviations used throughout is available for reference. Still, my research shows that the compiler resorted to a set of standard abbreviations, such as $s$. for substantive, a. for adjective, adv. for adverb, v.t. for verb transitive and int. for interjection, which were employed consistently ever since the publication of Rykaczewski’s English-Polish dictionary (1849).

${ }_{34}$ The IPA was first introduced into English-Polish bilingual dictionaries by Stanisławski ( A new English-Polish and Polish-English dictionary, 1945). 


\subsubsection{Labels}

Only a handful of labels have been discerned in the entries, e.g. Am. for American (octillion), min. for mineral (obsidian), med. for medicine (obstipation), ent. for entomology (obumbrate), zool. for zoology (ocelot), abbr. for abbreviation (Oct.), bot. for botany (oculus), chem. for chemistry (octane), fig. for figuratively (obscuration), hist. for historicism (obley) and S.H. (?) (observance). ${ }^{35}$ While obtected 'przykryty częścią sąsiednią, dostrzegalny, widoczny spod zewnętrznej powłoki /o poczwarce/' and obumbrate 'ukryty pod, zakryty' are treated as entomological terms both in the COD and the Century, ocellar 'odnoszący się do oczu bezkręgowców' or ocarina 'okaryna' are not labelled accordingly by Krzyżanowski.

\subsubsection{Sense division and semantic information}

Needless to say, the choice and shape of target language (TL) translation equivalents expressing the meanings of source language (SL) headwords is part and parcel of bilingual dictionaries. It is therefore crucial to look at this aspect of Krzyżanowski's sample. Table 1 below displays a handful of entries checked against Rykaczewski, Kierst and Stanisławski (pronunciations excluded).

\begin{tabular}{|c|c|c|c|}
\hline Krzyżanowski & Rykaczewski & Kierst & Stanisławski \\
\hline $\begin{array}{l}\text { oast s. - -house su- } \\
\text { szarnia /chmielu, ty- } \\
\text { toniu/. }\end{array}$ & - & - & $\begin{array}{l}\text { oast } r z \text {. suszarnia } \\
\text { (chmielu) }\end{array}$ \\
\hline $\begin{array}{l}\text { oat, s. zwykle oats } \\
\text { s.pl. owies; to sow } \\
\text { one's wild - s, wyszu- } \\
\text { mieć się /o młodzie- } \\
\text { ży/. - -cake s. placek } \\
\text { owsiany. - } \underline{\text { en a. owso- }} \\
\text { wy, owsiany. -en pipe } \\
\text { fujarka. - groats s.pl. } \\
\text { kasza owsiana. }\end{array}$ & $\begin{array}{l}\text { OAT, s. owies, zob. } \\
\text { OATS; (w składa- } \\
\text { nych); - bread, chleb } \\
\text { owsiany. - cake, pla- } \\
\text { cek owsiany. - meal, } \\
\text { mąka owsiana, kru- } \\
\text { py owsiane. } \\
\text { OATS, s. s.pl. owies. } \\
\text { To sow one's wild -, } \\
\text { (prov.), wyszumieć } \\
\text { się z szału młodości, } \\
\text { ustatkować się. }\end{array}$ & $\begin{array}{l}\text { oat, oats, owies; to } \\
\text { sow one's wild -, wy- } \\
\text { szumieć (o młodzie- } \\
\text { ży). -en } a \text {, owsiany, } \\
\text {-smeal, oatmeal } s \text {, } \\
\text { owsianka. }\end{array}$ & $\begin{array}{l}\text { oats, } l m n \text {. } r z \text {. owies; } \\
\text { sow one's wild } \sim \text {, wy- } \\
\text { szumieć (o młodzie- } \\
\text { ży); -en pm. owsiany; } \\
\text {-meal } r z \text {. owsianka, } \\
\text { mąka owsiana. }\end{array}$ \\
\hline $\begin{array}{l}\text { obdura/cy s. zatwar- } \\
\text { działość, zaciętość. } \\
\text { - te /obdjurit/ a. za- } \\
\text { twardziały, zacięty, } \\
\text { zawzięty. - te } \text { tobd- }^{1} \text { /obd } \\
\text { jureit/ v.t. uczynić } \\
\text { moralnie zatwardzia- } \\
\text { łym (...) }\end{array}$ & $\begin{array}{l}\text { OBDURACY, s. za- } \\
\text { twardziałość, zacię- } \\
\text { tość, upór. } \\
\text { OBDURATE, adj. } \\
\text { zatwardziały, zacięty, } \\
\text { uparty (...) }\end{array}$ & $\begin{array}{l}\text { obdura/cy } s \text {, zatwar- } \\
\text { działość w złem. -ate } \\
\text { a, zatwardziały. -ate- } \\
\text { ness s, zatwardziałość, } \\
\text { zaciętość. }\end{array}$ & $\begin{array}{l}\text { obdura-cy } r z \text {. zatwar- } \\
\text { działość (w złem); } \\
\text { upór; -te pm. zatwar- } \\
\text { działy, uparty. }\end{array}$ \\
\hline
\end{tabular}

35 It is possible that S.H. stood for Scottish History (cf. the SOED's list of abbreviations). 
Krzyżanowski

objurgat/e v.t. łajać, strofować, dać naganę. -ion s. łajanie, strofowanie, nagana. -ive, -ory a. łający, strofujący.

obscene a. nieprzyzwoity, wszeteczny, plugawy, sprośny. -ely adv. nieprzyzwoicie, wszetecznie, plugawie, sprośnie. -eness, -ity s. nieprzyzwoitość, wszeteczność, plugawość, sprośność.

obstreperous a. 1/ hałaśliwy, wrzaskliwy, krzykliwy. 2/ niesforny. -ly adv. 1/ hałaśliwie, wrzaskliwie. 2. niesfornie. -ness s. 1/ hałaśliwość, wrzaskliwość. 2/ niesforność.

octo/ped s. ośmionóg (...) -pus s. ośmiornica.

Rykaczewski

Kierst

Stanisławski

TO OBJURGATE, v.a. łajać, buzować, zgromić.

OBJURGATION, $s$.

łajanie, zgromienie, bura.

OBJURGATORY, adj. łający, gromiący, strofujący.

OBSCENE, adj. sprośny, wszeteczny; -LY, $a d v$. sprośnie, wszetecznie; -NESS, zob. OBSCENITY.

\section{OBSTREPEROUS,} adj. hałasujący, huczny, krzykliwy, wrzaskliwy; -LY, adv. z krzykiem, z hałasem, hucznie; -NESS, $s$. krzykliwość, wrzaskliwość. obscene $a$, plugawy, sprośny.

obscenity, sprośność, bezwstyd. objurga-te, strofować, łajać; zgromić; -tion $r z$. strofowanie; wyłajanie; zgromienie; -tory, pm. strofujący, gromiący.

obscen-e $p m$. plugawy, sprośny; -ity $r z$. sprośność, bezwstyd; wszeteczność. obstreperous $a$, krzykliwy, wrzaskliwy, niesforny. -ness $s$, krzykliwość, niesforność. obstreperous $p m$. krzykliwy, wrzaskliwy, niesforny; hałaśliwy; huczny.

Table 1. A comparison of Krzyżanowski, Rykaczewski, Kierst and Stanisławski.

Kierst's and Stanisławski's influence is visible at first sight, both in the selection of TL equivalents and, more generally, in the lexicographic design. One of the similarities is niching items in the entry to save space, although this technique has two major drawbacks. Firstly, the main headwords are often derivatives rather than root words (e.g. observable instead of observe). Secondly, a large number of run-ons affects negatively the retrievability of lexicographic information (or the look-up process) and, in this way, contributes to the dictionary's user-unfriendliness (see Fig. 2 below).

Quite unexpectedly, Table 1 points likewise to the borrowing from Rykaczewski's dictionary. Krzyżanowski clearly appreciated not only his predecessor's equivalents (e.g. 'zaciętość' for obduracy or 'łajać' for objurgate), but also his range of compounds (e.g. oatcake 'placek owsiany' in the entry for oat), derivatives 
(e.g. obstreperously) and, as it seems, contextual uses. ${ }^{36}$ Thus, all the three bilingual volumes were presumably consulted to make sure that the dictionary under compilation would be free from blatant errors.

observ/able /ab'zə:vəbl/a. I/ mający być przestrzegany, zachowany. 2/ dający się zauwazyć, dostrzegalny, sportzzegalny. 3/ godny uwag1. - ably /abli/ adv. w sposób zasxugujący na uwagę. - ance /ab'za:vans/s. I/ zachowywanie, przestrzeganie /zwyczajów, praw/. 2/ zwyczaj, obyczaj. 3/ reguxa zakionna /szczeg. franciszkańska/. 4/ archa1c. uprzejmość, usłuźność. 5/ SH. zauważenie, zwrócenie uwagi. - ancy /ansi/s. archaic. = observance. - ant /ont/ a. I/ przestrzegqjący, dochowujący. 2/ uprzejmy, pexen uszanowania. 3/ uwrìający. 4/ uważny, xatwo dostrzegający. - ; - ine / / s. franciszkanin reguxy śc1sxej. - ation /Jbza(:) vei $\{a n /$ s. I/ dostrzeganie, przestrzeganie, spostrzezenie. I/ obserwowanie, obserwacja. 3/ oznaczanie wysokośc1 słońca/lub innych c1ax niebieskich/. 4 uwaga. - ational /eijanl/ a. obserwacyjny, zawierający uwagi. - ationally /eifneli/ adv. obserwacyjnie. - ation-car /e1/an-ka*/s.Am. wagon obserwacyjny. - atory /ab'zə:vatr1/ a. dotyczący obserwacj1 naukowych, obsemacyjny. - s. obserwatorium. - e /ab'za:v/ v.t.\&1. I/ przestrzegać, zachowymać, obchodzić, stosować s1ę do. 2// oglądać, przyglądać się, obserwować, czynić obserwacje naukowe. 3/ oznaczać wysokość słołca. 4/ zauważyć, wypowiedzieć uwagę, zdanie. - edly /dli/ adv. - er $/ \partial^{*} /$ s. I/ przestrzegający, zachownjący /obrczaj, prawo/. 2/ obserw tor. - ership $/ a^{*} i p /$ s. 2 - ing /in/ a. przestrzega. jący, uważny. - Ingly /injl/ adv. przestrzegająco, uwaźnie.

Fig. 2. The entry for observable in Krzyżanowski’s dictionary (courtesy of the PIASA).

The sample is left incomplete, because occasional Polish equivalents are written in pencil (e.g. oblate ' 'osoba oddana pracy klaszt. lub religijnej. Zakonnik oddany (?) pracy') or are not recorded at all (e.g. oblongatal). There are a number of question marks, not only in blanks but also above specific equivalents, as in the entry for obstupefy 'ogłuszyć' and subentry for obnoxiousness 'wzbudzanie niechęci', which were probably added by Simmons during his review of the work. One can also come across handwritten notes in English, which are useful clues indicating the compiler's background materials. For example, the first sense of the headword obtrude (see Fig. 3 below) is followed by a string of English near-synonyms, 'to thoust (?) out, eject, expel, push out'), which may have been taken from the SOED ('to thrust forth; to eject, push out'). ${ }^{37}$

36 Krzyżanowski recorded the expression to sow one's wild oat (under oat), but the TL translation indicates that it is more likely to have been taken from Kierst or Stanisławski.

37 I used the 1970 edition of the SOED (first published in 1933), because there seems to be little change in the bulk of the material and earlier editions were not available to me. 


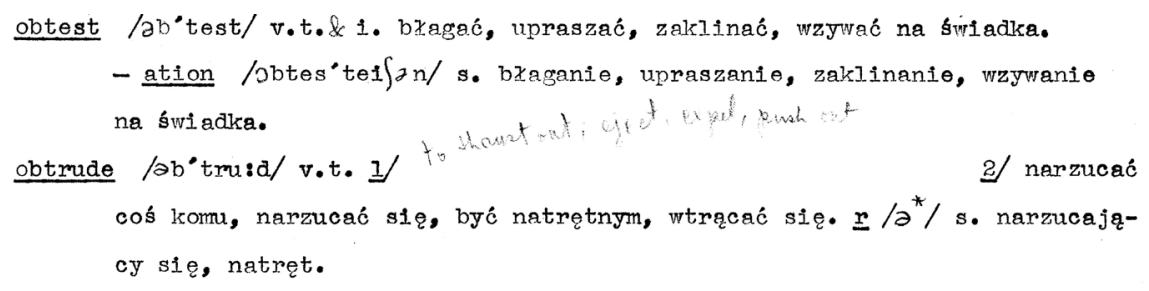

Fig. 3. The headword obtrude and its English synonyms in pencil (courtesy of PIASA).

Since monolingual English dictionaries were consulted for Krzyżanowski's wordlist, it can be taken for granted that they were also a source of semantic information for headwords missing from the English-Polish volumes. Indeed, in a comparative perspective, Krzyżanowski's dictionary shows a striking affinity to the COD and the Century. A few examples are displayed in Table 2 (COD) and Table 3 (the Century).

\section{Krzyżanowski}

$\underline{\mathrm{o}^{2}}$ s. prefiks patronimiczny w nazwiskach irlandzkich, syn, potomek, O’Connor.

$\mathrm{o}^{3}$ prep. $1 /$ abbr. of $\mathrm{w}$ zwrotach o'clock, Jacko-lanthern, Will-o-the-wisp, man-o-war. 2/ abbr. on cannot sleep o'nights.

oaf s. 1/ archaic. dziecko elfa, duszek (...)

oak (...) the O-s nazwa wyścigów trzylatków w Epsom (...)

ocean s. 1/ ocean; Atlantic O- ocean Atlantycki, Atlantyk; Pacific O- ocean Spokojny, Pacyfik; Indian O- ocean Indyjski; Arctic Oocean Lodowaty Północny; Antarctic O- ocean Lodowaty Południowy; German O- morze Północne. 2 / masa ogrom. - greyhound s. szybki statek/szczeg. pasażerski/. - -lane s. szlak przepisowy dla statków. -tramp s. nieregularny statek towarowy. O-ia n.pr. Oceania.

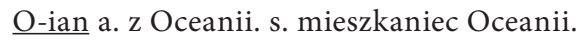
-ic a. oceaniczny. O-id s. oceanida, nimfa. -ographer s. oceanograf. -ographic(al) a. oceanograficzny. -graphy s. oceanografia. -wards adv. ku oceanowi, w stronę oceanu.

\section{COD}

O', pref. of Irish names, as O'Connor.

$\mathbf{o}^{2}$ prep. short for of, on, still in some phrases as (=of) o'clock, Jack-o'-lantern, Will-o'-thewisp, man-o'-war, (=on) cannot sleep o'nights.

oaf, n. Elf's child, changeling (archaic) (...)

oak (...) the Oaks, race at Epsom for threeyear-old fillies (...)

ocean, n. Great body of water surrounding the land of the globe; one of the main areas into which geographers divide this (usu. reckoned as five, the Atlantic, Pacific, Indian, Arctic \& Antarctic Oo.; German O., North Sea); the sea; immense expanse or quantity of anything (often oo. of); o. greyhound, swift ship, esp. passenger liner; $o$. lane, track prescribed for steamers; o. tramp, cargo-carrying steamer not engaged in single trade. Hence, oceanography n., oceanographic(al) aa., oceanward(s) adv.

Oceania, n. islands of Pacific \& adjacent seas. Oceanian, a \& n. (Native) of Oceania. oceanic, O-, a. Of, like \&c., the ocean; of Oceania.

Oceanid, n. Ocean nymph of Greek mythology.

Table 2. A comparison of Krzyżanowski's dictionary and the COD. 
Other entries in the sample, like those of obcordate, observation-car and occipitally, are a sign that Krzyżanowski used the Century. Every now and then the English definitions appear to have been translated literally, but in most cases they were significantly truncated, apparently for space gains.

\section{Krzyżanowski}

the Century

$\underline{\mathrm{o}^{2}}$ s. prefiks patronimiczny w nazwiskach irlandzkich, syn, potomek, O'Connor.

$\mathrm{o}^{4}$ int. o, oh; o dear me miły Boże! 2/ s. O’s of Advent siedem hymnów adwentowych. O’s of St. Bridget, The fifteen O's piętnaście modlitw o męce Pańskiej, zaczynających się od O.

obcordate a. w kształcie odwróconego serca.

obelisk s. 1/ obelisk. 2/ krzyżyk /znak drukarski/.

[in pencil: odnośnik $w$ formie krzyżyka]

observation-car s. Am. wagon obserwacyjny.

occip/ital a. 1/ potyliczny. 2/ mający wielki tył głowy. - s. 1/ kość potyliczna. 2/ mięsień potyliczny. -itally adv. [?]. - -ut s. 1/ tył głowy. 2. kość potylicowa.

octateuch s. oktateuch, pierwszych osiem ksiąg Starego Testamentu.
$\mathbf{O}^{6}, \mathbf{O}^{\prime}$, A prefix common in Irish surnames, equivalent to Mac in Gaelic and Irish surnames (see Mac), meaning 'son', as in O'Brien, O'Connor, O'Donnell, O'Sullivan, son of Brien, Connor, Donnel, Sullivan, etc.

$\mathrm{O}^{2}$, Oh (..) $2 \dagger$ same as $h o^{1}$.- The O's of Advent, the Advent anthems, sung in the Roman Catholic and Anglican churches (...) The O's of St. Bridget, or The fifteen O's, fifteen meditations on the Passion of Christ, composed by St. Bridget. Each begins with O Jesu (...)

obcordate, $a$. In nat. hist., inversely heartshaped (...)

obelisk, $n$. (...) 2. In printing and writing, a sign resembling a small dagger $(\dagger)$, and hence also called a dagger (...)

observation-car, $n$. A railroad-car with glass or open sides to enable the occupants to observe the scenery, inspect the track, etc. [U.S.]

occipital, I. $a$. 1. Of, pertaining to, or connected with the occiput or hindhead: opposed to sincipital.- 2 . Having a comparatively large cerebellum (...) II. $n$. In zoöl. and anat., the occipital bone (...)

occipitalis, $n$. A wide thin muscle arising from the superior curved line of the occipital (...)

occipitally, $a d v$. As regards the occiput; in the direction of the occiput.

(...)

occiput, $n$. 1. In man, the hinder part of the head, or that part of the skull which forms the hind part of the head (...)

Octateuch, $n$. A collection of eight books; specifically, the first eight books of the Old Testament considered as forming one volume or series of books (...)

Table 3. A comparison of Krzyżanowski's dictionary and the Century. 
As to the decision which compounds and derivatives should be given headword status, the author was influenced both by the COD and the Century; that is why he admits German ocean or ocean greyhound from the former and O's of Advent or the fifteen O's from the latter.

Occasionally, the reliance on the above dictionaries has been harder to prove. This pertains to such items as obeah, cross-referenced to obi (a more widespread spelling variant) in the Century, and occidentals 'mieszkaniec zachodu, człowiek należący do kultury zachodniej' (occidental). In this case, the SOED looks like a probable source of both entries (see Table 4$).{ }^{38}$

Krzyżanowski

obeah s. 1/ amulet, fetysz murzyński. 2/ rodzaj czarów uprawianych przez murzynów zach. afr. - -

occident s. zachód, zachodnie kraje Europy, Ameryka. -al a. zachodni, zachodnio-europejski. -s / mieszkaniec zachodu, człowiek należący do kultury zachodniej. -alism s. zachodniość, przynależność do kultury zachodniej. -alist s. 1/ zwolennik kultury zachodniej. 2/ badacz języków, ustrojów, instytucji zachodnich. - -ality s. = occidentalism. - -alize v.t. upodobnić do zachodu, uczynić zachodnim. -ally adv. zachodnio, na sposób zachodni.

\section{SOED}

|| Obeah, obi, $s b .1764$. [West African.] 1. An amulet, charm, or fetish used by negroes for magical purposes 1796. 2. A kind of pretended sorcery or witchcraft practised by the negroes in Africa, and formerly in the West Indies 1764. 3. attrib. as obeah (or obi) - man, a negro sorcerer, etc. 1764 (...)

Occident (...) B. $s b$. †a. A Western country or region; the o., the west 1829 . b. A native or inhabitant of the West 1857. Hence, Occide.ntalism, o. quality, style, character, or spirit; the customs, institutions, etc. of Western nations. Occide.ntalist, one who favours Western customs, modes of thought, etc.; one who studies the languages and institutions of Western nations. Occidentality, Occidentalize $v$. to render o. Occidentally $a d v$.

Table 4. A comparison of Krzyżanowski's dictionary and the SOED.

Lack of lexicographic information in other entries, like occasion, seems somewhat awkward. Why should Krzyżanowski leave a blank for the nominal meaning of occasion if the Century includes ten different senses of it? On top of that, Rykaczewski offers a handful of ready-made Polish equivalents ('okazya, zręczność, pora, pogoda, sposobność; pochop, powód, przyczyna, przypadkowa potrzeba’) and so does Kierst ('nadarzona okoliczność, stosowna pora, sposobność; 2) wydarzenie, zdarzenie; 3) okazja; 4) potrzeba, powód, przyczyna') and Stanisławski ('stosowna pora, sposobność; wydarzenie, zdarzenie; okazja, przyczyna'). Other main or secondary headwords which are not accompanied by TL equivalents include, for instance, Bible oath, bodily oath, oblongatal, observership, octandria, octastich, octile, oculomotor and ocydrome.

38 It should be noted that, in contrast to the SOED, Krzyżanowski entered both headwords correctly in a lower-case letter. 
Another issue worthy of attention is the order of senses. In monolingual dictionaries, one may encounter different arrangement techniques, two of which are the key ones: historical or chronological arrangement (from the oldest to the youngest sense) and frequency-based arrangement (from the most to the least frequent sense). ${ }^{39}$ Taking into account Krzyżanowski's article, his preference was clearly for the latter, but the order of the senses in the sample illustrates the former, being derived from dictionaries based on historical principles, that is, the COD, the Century and the SOED.

\subsubsection{Cross-references}

Even the tiny sample proves that Krzyżanowski planned to build a cross-referencing structure (cf. obi $=$ obeah, obd., obdt. abbr. = obedient, obelus = obelisk 2 , ocher $=$ ochre, Oct. abbr. October, Odinic = Odinian). As might be expected, the cross-referenced headwords were taken from the bilingual and monolingual dictionaries mentioned in the previous sections.

\section{Conclusions}

The aim of this paper was to evaluate the quality of Krzyżanowski's sample dictionary deposited in the PIASA archives. In doing so, I attempted to shed some light on facts and persons previously unrelated to the history of English-Polish and PolishEnglish lexicography.

What are the strengths and weaknesses of the typescript dictionary? An exhaustive wordlist (both main and secondary headwords), pronunciations in the IPA transcription and comprehensible TL equivalents must be perceived as the dictionary's strong points. Speaking of the weaknesses, there are too many obsolete and rare words, evidently superfluous in a dictionary of contemporary vocabulary, too many run-ons in the entry and too many descriptive equivalents instead of singleword equivalents. At the same time, Krzyżanowski recorded too few contextual uses and occasionally failed to provide labels for specialist terms.

The material confined solely to 18 pages does not allow for a comprehensive study, but the lexicographic conception is clear enough. What about the dating of the sample then? The comparative analysis remains inconclusive, because Krzyżanowski's sources were all published before 1939, so they could be used both in the compilation of the 1939 dictionary (in Poland) and the 1949 one (in America). That the sample was reviewed by Simmons, however, may be indicative of the fact that it was an excerpt of the latter. In any case, it is striking that the theoretical assumptions sketched in Krzyżanowski's article were not necessarily reflected in his own reference work.

Summing up, while the bilingual dictionary undertaken by Krzyżanowski and Goldman in Cracow had no chance to get published during World War II,

39 Chronologically speaking, the former type of arrangement preceded the latter, which is typical of learner's dictionaries, particularly those based on corpora (see, e.g., Stein 2002: 76). 
a similar endeavour could undoubtedly come into being in post-war America. Dorosz (2010: 272) explains that Krzyżanowski's project was abandoned due to "financial and organisational difficulties". This phrase alludes to what practical lexicographers have been acutely aware of: the way from an idea to the final lexicographic product is full of pitfalls and it takes a lot of perseverance and entrepreneurship - not only intellectual effort and time - to successfully see one's project to completion.

\section{References}

\section{Primary sources}
COD $=$ the Concise Oxford dictionary of current English. 1929. [Adapted by H.W. Fowler and F.G. Fowler from the Oxford English dictionary. New edition revised by H.W. Fowl- er]. Oxford.
SOED = the Shorter Oxford English dictionary on historical principles. 1970. [First published in 1933; Prepared by William Little, H. W. Fowler, J. Coulson. Revised and edited by C. T. Onions. Third edition revised with addenda]. Oxford.

Bulas K., Whitfield F.J. 1959. The Kosciuszko Foundation dictionary: English-Polish, PolishEnglish. [vol. 1: English-Polish]. The Hague.

Bulas K., Thomas L., Whitfield F.J. 1961. The Kosciuszko Foundation dictionary: English-Polish, Polish-English. [vol. 2: Polish-English]. The Hague.

Dziewicki M. 1910. A miniature Polish-English and English-Polish dictionary. First part: PolishEnglish. Second part: English-Polish / Słowniczek-karzełek polsko-angielski i angielskopolski. Część pierwsza: polsko-angielska. Część druga: angielsko-polska. Trebitsch.

Fowler H.W. 1927. A dictionary of modern English usage. Oxford.

Goldman S. 1920. Stownik miniaturowy "Dux" angielsko-polski i polsko-angielski. Kraków.

Jones D. 1932. An English pronouncing dictionary (showing the pronunciation of over 50,000 words in international phonetic transcription). [Revised edition with supplement]. London.

Kierst W., Callier O. 1895. Słownik języka polskiego i angielskiego / English-Polish and PolishEnglish dictionary. [vol. 1-2]. Leipzig.

Kierst W., Callier O. 1906. Pocket-dictionary of the English and Polish languages ... in two parts / Słowniczek polskiego i angielskiego języka ... w dwóch częściach. [vol. 1-2]. Leipzig.

Kierst W. 1915-1916. Dokładny słownik angielsko-polski i polsko-angielski w dwóch częściach z wymowa wyrazów angielskich. [fascicles 1-6]. Warszawa.

Kierst W. (ed.). 1926-1928. Trzaski, Everta i Michalskiego słownik angielsko-polski i polskoangielski. Część pierwsza angielsko-polska. [vol. 1]; Trzaska, Evert \& Michalski A dictionary English-Polish and Polish-English. Second part: Polish-English. [vol. 2]. Warszawa.

Lilien E. 1944-1951. Lilien's dictionary. Part 1: English-Polish. Ernesta Liliena słownik. Cz. 1: Angielsko-polski. [fascicles 1-19]. New York.

Maryański M. 1906 [ $\left.{ }^{\circledR} 1905\right]$. Jedyny w swoim rodzaju przewodnik polsko-angielski i słownik polsko-angielski dla wychodźców polskich i przybyszów do Stanów Zjednoczonych Ameryki Pótnocnej i Kanady, ułatwić mający stawianie kroków pierwszych w kraju obcym i naukę języka angielskiego, z podaniem wymowy i brzmienia każdego wyrazu angielskiego według metody fonetycznej, z dołączeniem niektórych uwag, rad $i$ wskazówek. Chicago. 
Paryski A.A. 1899. Słownik polsko-angielski i angielsko-polski oraz nauka wymowy angielskiej. Toledo.

Rykaczewski E. 1849-1851. A complete dictionary English and Polish, and Polish and English ... / Dokładny słownik polsko-angielski i angielsko-polski ... [vol. 1-2]. Berlin.

Rykaczewski E. 1874. Alex. Chodźko's A complete dictionary English and Polish, compiled from the dictionaries of Johnson, Webster, Walker, Fleming and Tibbins, etc. [vol. 1-2]. Berlin.

Socz J.K. 1944. Słownik polsko-angielski i angielsko-polski z wymowa oraz skróty angielskie i tablice porównawcze miar $i$ wag. English-Polish and Polish-English dictionary giving imitated pronunciation of every English word and the English alphabet; abbreviations and comparative tables of measurements and weights. London.

Stanisławski J. 1929. Słownik angielsko-polski i polsko-angielski. Warszawa.

Stanisławski J. 1933. Słowniczek angielsko-polski i polsko-angielski / An English-Polish and Polish-English pocket-dictionary. Třebič.

Stanisławski J. 1945. A new English-Polish and Polish-English dictionary / Nowy słownik angielsko-polski i polsko-angielski. Kraków.

Stanisławski J. 1948. Najnowszy angielsko-polski i polsko-angielski słownik kieszonkowy I Newest pocket English-Polish and Polish-English dictionary. New York.

Stanisławski 1964 = Jassem W. (ed.). Wielki słownik angielsko-polski / The great English-Polish dictionary. [vol. 1]. Warszawa.

Stanisławski 1969 = Jassem W. (ed.). Wielki słownikpolsko-angielski / The great Polish-English dictionary. [vol. 2]. Warszawa.

Szumkowski L. 1908. Dykcjonarz kieszonkowy polsko-angielski i angielsko-polski. Zawiera 12000 stów polskich, 18000 słów angielskich. Chicago.

Whitney W.D. (ed.). 1889-1891. The century dictionary and cyclopedia. [available at: http:// www.global-language.com/century/]. New York.

Whitney W.D. (ed.). 1895. The century dictionary. An encyclopedic dictionary of the English language. [vol. 1-10]. [available at: http://www.global-language.com/century/]. New York.

[Whitney W.D. (ed.)]. 1913. The century dictionary and cyclopedia. [With a new atlas of the world. A work of general reference in all departments of knowledge. Revised and enlarged edition; vol. 1-12]. New York.

Wilde T.M. 1928. Słownik Smulskiego angielsko-polski i polsko-angielski. Słownik kieszonkowy. English-Polish and Polish-English Pocket Dictionary. Chicago.

\section{Secondary sources}

Baker E.A. 1920. Cassell's new English dictionary: With an appendix. London.

Bela T., Mańczak-Wohlfeld E. (eds.). 1998. Proceedings of the commemorative conference for Roman Dyboski (1883-1945), Kraków 1-2 June 1995. Kraków.

Dorosz B. 2010. Korespondencja Kazimierza Wierzyńskiego i jego żony Haliny z Ludwikiem Krzyżanowskim - listy z lat 1947-1958 i 1976-1977. - Archiwum emigracji: Źródła i materiały do dziejów emigracji polskiej po 1939 roku 1.2 (12-13): 271-304.

Dyboski R., Krzyżanowski L. (eds.). 1950. Poland in world civilization. New York.

Gillon A., Krzyżanowski L. (eds.). 1964. Introduction to modern Polish literature. An anthology of fiction and poetry. New York.

Gillon A., Krzyżanowski L. (eds.). 1975. Joseph Conrad. Commemorative essays. Selected proceedings of the International Conference of Conrad Scholars, Univ. of California, San Diego August 29-September 5, 1974. New York. 
Gross F. et al. 1981. A tale from an old city. - The Polish Review [Special issue dedicated to Ludwik Krzyżanowski] 26.1: 5-15.

Jajdelski W. 2002. Michat Wiszniewski's "Stownik polsko-angielski” (1854): The scholar and the dictionary he made. [Unpublished MA thesis, Wrocław University].

Kamińska M. 2014. A history of the "Concise Oxford Dictionary". [= Lodz studies in language 34]. Frankfurt am Main, Berlin.

Kridl M., Malinowski W., Wittlin, J. (eds.). 1943. For your freedom and ours: Polish progressive spirit through the centuries. [Preface by M. W. Davis; translation and editorial assistance by L. Krzyżanowski]. New York.

Kridl M., Wittlin J., Malinowski W. (eds.). 1944. The democratic heritage of Poland: "For your freedom and ours". An anthology. [Translated by L. Krzyżanowski and adapted by Mr. and Mrs. S. Sulkin]. London.

Krzyżanowski L. 1957. Needed: An English-Polish and Polish-English dictionary. - The Polish Review 2.1: 99-103.

Krzyżanowski L. (ed.). 1960. Joseph Conrad: Centennial essays. New York.

Krzyżanowski L. (ed.). 1961. Julian Ursyn Niemcewicz and America. New York.

Nowożycki B. 2011. Działalność Polskiego Instytutu Naukowego w latach 1942-1989. - Archiwum emigracji: Studia - szkice - dokumenty 1.2 (14-15): 267-288.

Obituaries 1986: Ludwik Krzyżanowski. - New York Times of 26 March 1986. [available at: http://www.nytimes.com/1986/03/26/obituaries/ludwik-krzyzanowski.html].

Pastusiak L. 2002. Z tajników archiwów dyplomatycznych (stosunki polsko-amerykańskie w latach 1948-1954). Toruń.

Pieczonka M. 1993. “Księgarnia Wydawnicza Trzaska, Evert i Michalski”: Działalność wydawnicza. Kraków.

Piotrowski T. 2001. Zrozumieć leksykografię. Warszawa.

Podhajecka M. [forthcoming]. Szkic z dziejów leksykografii dwujęzycznej: Paweł Sobolewski i jego słownik angielsko-polski (1840). - Prace Filologiczne.

Rospond S. 1946. Jan Goldman. - Pamiętnik Literacki 36.1.2: 165-166.

Siekierska K. 1985. Kijowskie polonika (Rękopisy XVI-XIX wieku w Bibliotece AN USSR w Kijowie). - Przegląd Humanistyczny 29.1.2: 129-142.

Sprawozdanie Dyrekcji Państwowej Szkoły Handlowej obecnie Państwowego Koedukacyjnego Gimnazjum Kupieckiego w Białej Krakowskiej za rok szkolny 1937/38 (1938). Biała [Krakowska].

Stein G. 2002. Better words: Evaluating EFL dictionaries. Exeter.

Strzałkowa M. 1959/1960. Jan Goldman (1907-1942). - Polski Słownik Biograficzny 8: 210-211.

Supruniuk A., Supruniuk M. 2012. Uciekinierzy z UMK: Jan Zygmunt Wilczyński i Kazimierz Bulas. - Głos Uczelni. Pismo Uniwersytetu Mikołaja Kopernika 12.322: 24-25. [available at: http://glos.umk.pl/2012/12/GU_12-2012.pdf].

Szkoła Hotelarska w Krakowie. Sprawozdanie Zarzadu i Dyrekcji za lata nauki 1932/33, 1933/34 i 1934/35 (1935). Kraków.

\section{Archival sources}

AUJ = Jagiellonian University Archive in Cracow

Jan Stanisławski's personal file S II 619

Sprawa odznaczenia lektora Jana Stanisławskiego ... (31 January 1957)

A registry of doctoral degrees of the Jagiellonian University

A copy of Ludwik Władysław Maria Krzyżanowski’s doctoral diploma 
ARCM $=$ Archives and Research Collections of McMaster University (Canada)

C.K. Ogden fonds

[available from: https://library.mcmaster.ca/archives/findaids/findaids/o/ogden.01.htm] Box 41: Correspondence of Ogden, C.K. and Massey, B. W. A. (1932-1935):

Letter from Massey to Ogden of 12 April 1933

Letter from Massey to Ogden of 22 August 1933

Letter from Massey to Ogden of 21 November 1934

PIASA $=$ Polish Institute of Arts and Sciences of America in New York (USA)

Fonds no. 49: Ludwik Krzyżanowski papers

[available from: http://www.piasa.org/archives/fonds-049.html]

Dictionary (a sample of the letter section “O”) (49.147.24-41)

Eleventh annual banquet and ball of "Medicus" (1977) $\rightarrow$ Krzyżanowski’s biography (49.2.119)

Goldman Jan to Ludwik Krzyżanowski. A letter of 29 October 1938 (49.5.13-16)

Kister Halina to Ludwik Krzyżanowski. A letter of 16 September 1940 (49.6.67)

Krzyżanowski Józef to Ludwik Krzyżanowski. An undated postcard (49.6.80)

Ludwik Krzyżanowski's draft papers (49.148.001-016)

Roman Dyboski: A tribute of a pupil by Ludwik Krzyżanowski (49.149.1-9)

The Ludwik Krzyżanowski Testimonial $\rightarrow$ Krzyżanowski’s biography (49.2.108-109)

Translations by Ludwik Krzyżanowski (49.85-116)

TNC = Tomasz Niewodniczański's Collection at the Royal Castle in Warsaw

Part of the "Roy Publishing" archive

Contract between Jan Stanisławski and J. Lorenz entered on 20 September 1929 